\title{
The Effect of Leadership Styles on Employee's Productivity in the Nigerian Oil and Gas Industry
}

\author{
Adegboyega Olayisade ${ }^{1} \&$ Olawumi D. Awolusi² \\ ${ }^{1}$ University of Roehampton, London, UK \\ 2Department of Accounting and Finance, College of Economics and Management, Kampala International \\ University, Kampala, Uganda \\ adegboyega.olayisade@roehampton-online.ac.uk, awolusi.olawumi@kiu.ac.ug
}

\begin{abstract}
The purpose of this study is to examine the effect of leadership style on employee productivity in the Nigerian oil and gas industry using Chevron Nigeria Limited as a case study. The study used a five-point Likert scale questionnaire consisting of forty questions covering autocratic, democratic, bureaucratic, laissezfaire, transactional, charismatic leadership styles and employee productivity variables. The questionnaire was deployed to one hundred and twenty-five respondents (125) and received ninety-three (93) valid responses. Statistical Package for the Social Sciences (SPSS) was used to analyze respondent responses. Demographic analysis, normality test, homoscedasticity, multicollinearity, reliability test (Cronbach's Alpha) were presented; results affirm the validity and reliability of research findings. The results of the descriptive and regression analysis indicate that the autocratic leadership style is the most predominant leadership style in the Nigerian Oil and Gas followed by laissez-faire, bureaucratic, transactional, democratic and charismatic leadership styles. The study concludes that leadership styles significantly influence employee productivity albeit different leadership styles have varying effects on employee productivity and varying leadership styles can co-exist within the same organization. The study highlighted various policy implications and recommendations. This study adds to the existing literature on leadership practice and is intended to be a reference point to scholars and researchers for further studies on leadership practices in the oil and gas industry.
\end{abstract}

\section{Keywords: Leadership style, employee productivity, regression analysis, Oil and Gas industry, Nigerian.}

\section{Introduction}

Leaders and leadership practice have been in existence since the onset of mankind. Man is a complex social being that can be simplistically categorized into two groups namely leaders and followers. The successes recorded by most human endeavors can be attributed to leadership quality (Matira \& Awolusi, 2020). Over the years, various scholars have studied the concept of leadership with the aim of understanding and improving the inherent benefits of effective leadership; these studies have given rise to several definitions of leadership (Blazi \& Awolusi, 2020; Matira \& Awolusi, 2020; Mukonga \& Awolusi, 2019; Olatunji \& Awolusi, 2019). One of the most popular definitions of leadership states that "leadership is the art of getting things done through people". While there are several and sometimes conflicting theories on leadership, what is immutable is that leaders inspire their followers and direct their actions towards the attainment of a set goal. The practice of leadership has evolved considerably over time and the need for leaders and leadership has witnessed a significant upswing over the years. Historically, leaders were simplistically selected based on lineage, wealth or by exhibiting distinguishing acts of velour. It was believed at that time that such individuals possessed innate talents and attributes that set them apart from others and conferred upon them the right to be leaders. This natural leadership selection process was the premise of the Great man theory (Matira \& Awolusi, 2020).

The great man theory suggests that leaders and leadership potential are inborn and that leaders are born and not made. Possession of certain innate characteristics identifies an individual for leadership positions while the lack of such almost certainly guarantees the individual's exclusion from leadership roles. Great leaders like Martin Luther King, Julius Caesar, Malcolm X, Muhammadu Buhari and others further contributed to the belief that great leaders are born and not made. These leaders were perceived to differ from the populace in that they possessed personal attributes that made them effective leaders. In earlier times, leadership was the sole preserve of the male gender and this influenced the naming of this theory as the great man theory however with the resurgence of several great female leaders this theory was later recognized as the great person theory. The varying successes and failures of several leaders resulted in an increased interest in the study of leadership practice, the common attributes that differentiate a successful leader from an 
unsuccessful leader and a deeper understanding of leadership and leadership practice. Further studies and research resulted in a shift in paradigm from the great man/great person leadership theory to the trait approach to leadership. Prompted by the great man theory of leadership, and the emerging interest in understanding what leadership is, researchers focused on the leader.

Who is a leader? What are the distinguishing characteristics of great and effective leaders? This gave rise to the early research efforts on the trait approach to leadership (Matira \& Awolusi, 2020; Mukonga \& Awolusi, 2019). The trait theory is premised on identifying and studying different personality traits and characteristics exhibited by successful leaders in diverse situations to develop similar traits and characteristics in others. By seeking to identify and understand traits and characteristics of successful leaders, the trait theory postulates that certain innate traits are common to leaders and that these traits are consistent across different situations; it assumes that people in leadership positions exhibit a higher degree of leadership traits than their followers. Over the years, there has been considerable academic study and research into leadership and leadership practice and behavior resulting in several other leadership theories and counter theories like the behavioral theory, participative theory, situational theory, functional theory, contingency theory, transactional leadership theory, authentic leadership theory and transformational leadership theory. Leadership and the choice of leadership style utilized have been thought to influence employee outcomes.

This is evident in the amount of resources organizations commit to developing leadership potential and employing personnel with requisite leadership potential in a bid to ensure competitive advantage is achieved in the area of employee productivity. Leadership practice and style impacts employee's performance by promoting "a climate that would influence employees' attitudes, motivation, and behavior" (Aldoory \& Toth, 2004 cited in Aunga \& Masare, 2017); this, in turn, impacts organizational success. Chevron Nigeria Limited is a company that attributes its success to its workforce and its commitment to get results the right way (Chevron, 2018). According to the company's 2017 corporate responsibility highlights, the company recognizes "the value of leadership as a critical success factor in achieving operational excellence results" (Chevron, 2018). A key facet of the company's enterprise strategies is investing in its workforce to develop and empower a highly competent workforce. The company's commitment to personnel development and leadership quality stems from its understanding of the importance of leadership. The company currently has several processes such as training, workshops and a performance management process in place to ensure persons in leadership positions exhibit leadership behaviors/styles that maximize employee productivity.

Activities in the Nigerian oil and gas industry are highly regulated due to the sector's significant contribution to the country. Employee and industrial issues are highly influenced by the actions of the two dominant trade unions namely NUPENG (Nigeria Union of Petroleum and Natural Gas Workers) and PENGASSAN (Petroleum and Natural Gas Senior Staff Association of Nigeria). These trade unions play a significant mediating role during salary negotiations and review, appraisals, promotions and disciplinary actions. This has resulted in the industry being one of the most attractive places to work due to its generous remuneration package which has made it one of the highest paying industries in the country (Onuoha, 2017). The attractive remuneration prevalent in the Nigerian oil and gas industry has enabled organizations within the sector to attract and retain the best the Nigerian labor market has to offer and in fact, the industry attracts highly qualified personnel from all over the world. While the presence of one of the most attractive salaries and remuneration packages enables organizations to attract and recruit an optimal workforce it is not an effective tool to sustain and motivate employee productivity outside the short term especially when career progression and salary increments are mainly in the domain of the trade unions.

This observation is supported by the study of Kohn (1993) whose review of several studies over the last three decades revealed that reward systems provide a temporary, short-lived incentive to motivate employee productivity. Understanding and identifying the predominant leadership styles and how it influences employee productivity is valuable to the development of existing and potential leaders charged with the responsibility of utilizing organizational resources (especially its human capital) to achieve organizational goals and objectives. There are several studies in existence that conclude that leadership and leadership styles greatly influence employee morale (Rego et al., 2012, Singh 2015) however there is a gap in the existing literature on how leadership styles affect employee productivity in the Nigerian oil and gas industry. In response to this gap, this study investigates the effect various leadership styles have on employee 
productivity in the Nigerian oil and gas industry using Chevron Nigeria limited as a case study. The choice of this research topic is influenced by the researcher's personal experience working in the Nigerian upstream oil and gas industry and the industry's peculiar situation on wage, reward and employment termination being influenced and determined by external parties (i.e. the trade unions) which have eroded the value of reward and employment termination as (employee) incentive schemes.

Consequently, the primary objective of this study is to examine the effect of leadership styles on employee's productivity in the Nigerian oil and gas industry. However, the specific objectives are as follows:

- To examine the effect of autocratic leadership styles on employee's productivity in the Nigerian oil and gas industry.

- To examine the effect of Participative Leadership styles on employee's productivity in the Nigerian oil and gas industry.

- To examine the effect of Bureaucratic Leadership style on employee's productivity in the Nigerian oil and gas industry.

- To examine the effect of Laissez-Faire Leadership style on employee's productivity in the Nigerian oil and gas industry.

- To examine the effect of Transactional Leadership style on employee's productivity in the Nigerian oil and gas industry.

- To examine the effect of Charismatic Leadership style on employee's productivity in the Nigerian oil and gas industry.

The creation and/or selection of research questions is a crucial aspect of research work as it influences the researchers' choice of research methodology, data collection, analysis and presentation (Ajayi 2001:24). Research questions guide and focus the research by asking questions that result in the development of a credible research thesis. To achieve the objectives of this study, the following questions will guide this study:

- What is the relationship between autocratic leadership styles and employee's productivity in the Nigerian oil and gas industry?

- What is the relationship between participative Leadership styles and employee's productivity in the Nigerian oil and gas industry?

- What is the relationship between bureaucratic Leadership style and employee's productivity in the Nigerian oil and gas industry?

- What is the relationship between Laissez-Faire Leadership style and employee's productivity in the Nigerian oil and gas industry?

- What is the relationship between transactional Leadership style and employee's productivity in the Nigerian oil and gas industry?

- What is the relationship between the charismatic Leadership style and employee's productivity in the Nigerian oil and gas industry?

The present study aims to improve employee productivity through leadership practice. It also seeks to examine the relationship between various leadership styles and employee productivity. Lessons learned from this study can help organizations understand their leadership styles and make adjustments, where necessary to maximize employee productivity; this is especially important to the Nigerian oil and gas industry in improving employee productivity outside of the traditional use of wage increments. The researcher hopes that the findings of this study will assist Chevron Nigeria Limited as well as other organizations in the oil and gas industry to develop training programs that will improve the leadership qualities required to impact employee productivity, recruit individuals with requisite leadership potential to ensure organizational growth as we as to enable the organization's management to identify the most appropriate leadership to optimize employee productivity. This study also seeks to contribute to the existing literature on leadership practice and be a reference point to scholars and researchers for further studies on leadership practice and other related subject matters.

\section{Review of Related Literature}

Conceptual Reviews: In today's fast-paced, dynamic and complex business environment, leaders need to be able to adapt and adopt a gamut of leadership styles required to effectively manage their followers based on 
the prevailing situation and organizational needs and objectives. There are several types of leadership styles available within an organizational context. Each style has its pro and cons and no single leadership style is better than the other. Leaders should be prepared to use more than one leadership style in their quest to influence their followers to achieve an objective. This had been dubbed as the Hawthorne effect. The choice of leadership style is influenced by several factors such as the prevailing situation, organizational culture, the desired objective/goal, individual preference as well as team dynamics.

Autocratic Leadership: Autocratic leadership is one of the oldest leadership styles in existence. This style is task-centered and focuses on getting tasks done. Power is concentrated in the hands of the leader who makes all the decisions, provides direction and assigns the task to subordinates (Kagwiria, 2016). Autocratic leaders are charismatic and self-assured individuals who typically do not require validation from their followers. "Autocratic leaders use their position to pursue aggressive and visionary goals and their power through organization culture, press and media to praise their initial success" (Men \& Stacks, 2013). The autocratic leadership style is best suited to situations where the leader possesses expert knowledge (e.g. an experienced surgeon leading medical interns) or where the leader is an authority figure whose authority is unalloyed (e.g. a superior officer in the army). The main advantage of the autocratic leadership style is that tasks get completed quickly and it ensures the supremacy of the leader. However, if improperly utilized followers may become disgruntled and this may impact organizational results.

Participative Leadership: This leadership style also known as the democratic leadership style is almost directly opposite of the autocratic leadership style. The participative leadership style focuses on collaboration between the leader and the followers; information is shared with the followers who participate in decision making, however, the lender retains the prerogative on the use and adoption of inputs from followers. Participative leadership encourages innovation and creativity by giving every member of the organization/team the ability to provide input into decision making which results in easy adoption and utilization of decisions taken (Dalluay \& Jalagat, 2016; Ispas, 2012; Iqbal et al., 2015; Mulki et al., 2015). This leadership style is most suited to organizations that thrive on innovation and creativity; these organizations consist of teams comprising of members with unique perspectives and skillsets (e.g. construction project team). While this leadership style encourages creativity, improved decision making and team cohesion, it is not appropriate when working with large teams or where urgent decisions need to be made.

Bureaucratic Leadership: This leadership style is premised on organizational structure and hierarchy. The leader's authority and acceptability stem from the position held within the organization. This type of leadership is based on formalized hierarchical leadership structures; leadership authority, scope and practice are all founded within the organizational construct. This leadership style is best suited to organizations such as banks, hospitals, professional services firms, etc. where a certain level of control, checks and balances is required to moderate leadership actions and behavior to militate against tyrannical leadership and abuse of power. This style is also effective where employees carry out routine jobs. The restrictive, static nature of the bureaucratic leadership style is one of its major failures. Employees often get demotivated by the difficulty in communicating their thoughts and suggestions up the chain of command. The lack of innovation and leadership adaptation to situations oftentimes makes the leader redundant and leads to a demotivational workforce (Gastil, 2012).

Laissez-Faire Leadership: Laissez-faire is a French word that describes the policy of leaving things to take their course, without interfering. This leadership style (also known as delegative leadership) is predominant in organizations/teams consisting of highly experienced personnel and is characterized by minimal leadership involvement. Laissez-faire leaders exercise minimal control over their employees; once employees have been provided with the necessary tools and resources to complete assigned tasks they are left alone to resolve issues on their own (Chowdhury, 2014). This leadership style is beneficial in creative environments as it encourages employee innovation and creativity which leads to improved job satisfaction. Laissez-faire leadership is not ideal in situations where group members lack the knowledge or experience they need to complete tasks and make decisions to the lack of supervision, mentorship, feedback and organizational structure often results in inefficient utilization of resources, failure to meet deadlines and failure to achieve desired objectives (Egri, 2011 cited in Kagwiria, 2016). 
Transactional Leadership: Transactional leadership style focuses on establishing roles and responsibilities and using a system of reward and punishment to motivate followers. Transactional leaders are result-driven and achieve their objectives through close monitoring of subordinates, interventions, rewarding desired behaviors and outcomes while punishing undesirable behaviors (Chowdhury, 2014). Transactional leadership is based on two main concepts namely contingent reward and management by exception. Contingent reward occurs where the leader provides a reward to the follower for exhibiting (previously agreed) behaviors and/or achieving a pre-agreed objective. The reward comes in various forms and could be financial, psychological, or materialistic. Management by exception, on the other hand, refers to a leadership style that is exception-based. The leader only intervenes when followers deviate from acceptable performance/behaviors and introduce remedial action to ensure desired outcomes are achieved.

Charismatic Leadership: This leadership style focuses on influencing followers through the leader's personality traits and behavior. Charismatic leaders use their unique personality and communication style to inspire and win the admiration of their followers; this results in a high level of commitment to the leader's cause and improved follower productivity. Charismatic leaders possess a high level of emotional intelligence, are very self-assured and have a high level of commitment to organizational objectives. They possess and use their ability to project their enthusiasm and commitment to their followers to motivate them to achieve desired objectives. The downside to charismatic leadership is that the success of the organization is linked to the presence of the leader. If the leader decides to leave the organization, it may lead to demotivation among the employees and this may require substantial efforts by the organization to remediate. This study seeks to identify the various leadership styles prevalent in Chevron Nigeria Limited and determine the effect leadership styles have on employee productivity.

Theoretical Reviews: This study was guided by the following leadership theories; participative, path-goal, situational and transformational leadership theory:

Participative Theory: The participative leadership theory is premised on a leadership style that encourages input, contributions and participation from employees and team members. The theory's roots can be traced back to the early 1930s when the results of an experiment conducted at the Hawthorne Works in Illinois, US, were analyzed by Elton Mayo and others. The experiment was aimed at finding ways to improve factory productivity, although the findings related more to motivation. The findings relating to participatory leadership saw light in the 1950s when researcher Henry A. Landsberger examined the original experiments led by Mayo. Landsberger found that workers' productivity increased during participation in the experiment because they were being observed. This had been dubbed as the Hawthorne effect. According to Crane, the experiments show that when employees feel supported through observation and participation, they are more satisfied and therefore productivity increases. Participative leaders provide pertinent information to subordinates and encourage feedback and contributions to facilitate decision-making. Participative leadership results in increased stakeholder participation, collaboration and commitment; this oftentimes results in improved decision making, easy adoption and implementation of decisions taken (Dalluay \& Jalagat, 2016; Ispas, 2012; Iqbal et al., 2015; Mulki et al., 2015). Antagonists of this theory are quick to point out that it utilizes more resources, requires more time to arrive at decisions and is susceptible to bias when the leader is presented with a wide range of alternatives. Participative leadership thrives in organizations with low power distance culture hence its popularity in the United States and other Western-influenced organizations.

Path-Goal Theory: The Path-Goal leadership theory is based on the Vroom expectancy theory in which an individual will act in a certain way based on the expectation that the act will be followed by a given outcome and on the attractiveness of that outcome to the individual. The path-goal theory was developed by Martin Evans in his 1970 paper, "The effects of Supervisory Behavior on the Path-Goal Relationship" and was refined by Robert House in his 1971 paper, "A Path-Goal Theory of Leader Effectiveness". According to House (1971) \& Malik (2013), "the theory is based on specifying a leader's style or behavior that best fits the employee and work environment to achieve a goal". Simplistically, this theory can be explained as that leadership style whereby a leader exhibits certain contextual behaviors that align the follower's goals with the organization's goals and direct the followers to choose the best paths to achieve these goals (Malik, 2013). The goal of this leadership style is the improvement of employee productivity by focusing on employee satisfaction and motivation. "The Path-Goal theory posits that leaders may not only use varying behaviors with different 
subordinates but might use different behaviors with same subordinates in different situations" (Richard et al., 2012 cited in Malik, 2013). The theory posits that leaders may use different behaviors with the subordinates in a similar situation and/or employ varying behaviors with the same subordinate in different situations. Path-goal theory suggests that depending upon subordinates, and situations, different leadership behaviors will increase acceptance of leader by subordinates; level of satisfaction; and motivation to improved performance.

Situational Theory: Situational leadership theory is a contingency theory whereby leadership is fluid and varied; the leader adopts a leadership style that best suits the existing situation or circumstance. Different situations and employees may require different leadership styles e.g. a democratic leadership style is best suited when employee input and participation is required (say for example a new leader might need the inputs of his more experienced team in resolving a situation) while an autocratic leadership style might be required in an organization or team with high power distance culture (e.g. a newly promoted general in the army). Leadership effectiveness under the situational leadership theory is dependent on leadership behavior, follower readiness and leader-follower match (Luo \& Liu, 2014; Graham \& Trendafilova, 2016).

Leadership Behavior: Supportive (relationship) behavior and directive (task) behavior are the two main leadership behaviors under situational leadership. Supportive behavior involves the leader taking more of a support role by seeking subordinates' ideas and contributions and ensuring subordinates feel included in the decision-making process while directive behavior is more task-oriented and involves supervision, providing direction, using one-way communication and walk-throughs to set and clarify how objectives should be achieved.

Follower Readiness: Follower readiness as the name implies is the measure of the responsiveness of a subordinate to his leader. The major influencing factors of follower readiness are ability and willingness. Ability is concerned with the competence of the subordinate to successfully execute assigned tasks while willingness is the degree of readiness to perform assigned tasks (Graham \& Trendafilova, 2016).

Leader-Follower Match: Leader-follower match is the focal point of situational leadership theory and is concerned with the leader's adoption of a leadership style most appropriate for the prevailing situation after taking into consideration the follower's level of readiness (Luo \& Liu, 2014). Situational leaders inspire trust and motivate their followers to improved productivity by proactively altering their behaviors to suit existing situations and help their followers maximize their potential.

Transformational Leadership Theory: The transformational theory also known as relationship theory focuses on the connections formed between leaders and followers. This theory is premised on a leadership style that inspires followers to improved performance by focusing on the wants and needs of the organization as well as the personal concerns of its members (Munir \& Aboidullah, 2018). Leadership effectiveness under this theory is dependent on individualized consideration, intellectual stimulation, inspirational motivation and idealized influence (Bass, 2000 cited in Ewell, 2018 and Getachew \& Erhua, 2018). According to several researchers (Ewell, 2018; Getachew \& Erhua, 2018), "Idealized influence refers when transformational leaders act as a role model to their subordinates such that the followers identify themselves to a high level of morale and enthusiasm to fulfill the demands of leader whom they respect, admire and trust (Bass, 2000). Inspirational motivation highlights leaders' motivation and inspiration of followers by giving self-worth for their contribution and setting challenges to their followers (Bass \& Avolio, 2000). Intellectual stimulation is encouraging followers to do tasks distinctly by being innovative and creative. Individualized consideration refers to giving special attention to the needs of every individual follower for their achievement and personal growth (Bass, 2000:34)". Leaders using this approach can motivate others, "to want to change, to improve, and to be led" (Hall, 2002 cited in Ewell, 2018) and possess high ethical and moral standards.

\section{Empirical Reviews}

Employee Productivity: Productivity can be defined as the effectiveness of factors of production (i.e. inputs) in generating desired outcomes efficiently. Successful organizations are characterized by a high level of productivity; they are companies that have achieved a competitive advantage in the utilization of available 
resources to obtain desired outputs. One of the areas organizations seek to have a competitive advantage in recent times is in their human resource. Human resource and human resource management are concerned with the practice of recruiting, motivating and managing employees to maximize employee productivity and achieve organizational objectives. Hassan (2016) \& Singh (2015) affirm that employee productivity is directly correlated to organizational success. Employees are the tools management uses to achieve their objectives and their actions or inactions influence the profitability and viability of organizational success. Employee productivity is an assessment of the effectiveness and efficiency of an organization.

Successful organizations understand the importance of productivity in the workplace; increased employee productivity results in increased utilization of a firm's human capital. Traditionally, organizations used remuneration, bonuses, pay for performance and wage increments to motivate the employee and ensure improved productivity. Mangale (2017) concludes that remuneration is insufficient to retain and motivate employees; attractive remuneration might attract employees, but it is not guaranteed to ensure retention and improved productivity as repeated use of remuneration might be perceived by employees to be an entitlement and not a motivator. Furthermore, the studies confirmed that the relationship between top management/leadership influences employee productivity. This assertion has been countered by the works of researchers such as Ojeleye (2017), Mwangi (2014), Wilfred et al. (2014), who assert that remuneration attracts, retains and motivates employees and for the "compensation of an organization to succeed, the goals of the organization must be aligned with the goals of the employees whom the organization wishes to attract" (Wilfred et al., 2014).

Influence of Leadership Style on Employee Productivity: Successful organizations always seek to attract, retain and develop leaders who can motivate their subordinates to meet and/or exceed performance expectations and are flexible enough to respond to changes within and outside their environment. Rehman et al. (2018)'s study of leadership styles organizational culture and employees' productivity: Fresh Evidence from Private Banks of Khyber-Pakhtunkhwa, Pakistan was undertaken with a primary objective of investigating the impact of leadership styles and organizational culture on employees' productivity. Both qualitative and quantitative research method was used in arriving at the research finding that a significant positive relationship exists between employees' productivity and several leadership styles such as laissezfair, transactional and transformational leadership styles. The study also posits that neither autocratic nor a democratic style of leadership has a significant positive association with employees' productivity. This study has some obvious limitations including the use of a small sample size, poor questionnaire responses and limitation of the research work to Pakistan and its inherent power distance culture. Ajibade et al. (2017) examine leadership style and employees' performance in Nigerian Federal Polytechnic: a study of Federal Polytechnic, Ilaro, Ogun State. The main objective of this study includes identifying the relationship between leadership style and employee's performance using primary and secondary research data.

The study concludes that there is a significant relationship between leadership styles and employee's performance in Nigerian Federal Polytechnics. The study further identifies that the success or failure of an organization depends on its leaders and the leadership style adopted within the organization. Marcus et al. (2017) studied the impact of leadership styles and employee performance in Nigerian higher institutions. The study utilized primary and secondary data through the use of questionnaires and literature review respectively. The study revealed that leadership style affects employee performance, needs and goals. Singh (2015) reviewed leadership style and employee productivity: a case study of Indian banking organizations. The study used a quantitative approach to achieve the research objective of understanding the relationship between leadership styles and employee productivity with an emphasis on private and foreign banks in India. Data were collected using self-administered questionnaires; a total of three hundred (300) questionnaires were distributed with a response rate of $69 \%$. The findings of the research indicated that although leader leadership style improves employee productivity, the prevailing power distance culture in the organization needs to be considered when choosing an appropriate leadership style e.g. in India where there is a highpower distant culture, transactional leadership style is appropriate for improving employee productivity while transformational leadership style is better suited for the (western-influenced) foreign banks.

Chodhury \& Gopal (2014) explored how leadership styles influence employee motivation in India's leading oil company. Survey technique and review of existing literature were used to source primary and secondary 
research data respectively. The research concluded that transformational and transactional leadership styles were the most dominant leadership styles and that different leadership styles impact employee motivation in a variety of different ways. The findings of this research work are not holistic as it is limited to one company from the Indian oil sector; additional research work will have to be done before the research finding can be extended to a larger population. Obasan \& Banjo (2014)'s study of the impact of leadership styles on employee performance used the (Nigerian) Department of Petroleum Resources as a case study. The paper focused on select leadership styles and how these styles impact employee performance and used primary data generated by deploying one hundred questionnaires through a stratified random selection of respondents. The study compared the effect of transactional, transformational, and laissez-faire leadership styles have on employee performance and concluded that transformational leadership style is the most effective leadership style and recommends that "managers should use more of transformational leadership to bring about higher levels of organizational commitment, OCB and job satisfaction" (Obasan \& Banjo, 2014). Pradeep \& Prabhu (2011) did research on the relationship between effective leadership and employee performance.

The researchers obtained research data by deploying two hundred and fifteen (215) surveys across seven companies in India's private and public sector; 199 surveys were returned representing a response rate of $92.56 \%$. The result showed that while leadership is positively linked with employee performance, there is no universally acceptable conclusion as to what effective leadership is. Various factors such as cultural differences, employee attitude and expectations, organizational policies and power distance all influence the effectiveness of leadership practice. There exists a plethora of literature on leadership and employee productivity and their results, findings and recommendations of these studies are somewhat varied; while several researchers posit that several leadership styles e.g. transformational and transactional leadership styles are significantly correlated to employee productivity and there is inconclusive evidence on the effect other leadership styles e.g. laissez-faire (Marcus et al., 2017; Singh, 2015; Chodhury \& Gopal, 2014; Obasan \& Banjo, 2014), several other studies refute this assertion claiming a counter assertion (Rehman et al., 2018; Pradeep \& Prabhu, 2011). This is indicative that there is no universally acceptable hypothesis on leadership style and employee productivity. The existing literature on leadership behavior and employee productivity while extensive is not exhaustive.

The existing literature reviewed in the previous section spans several countries and industries; ranging from India to Pakistan and Nigeria and covering the banking, education, oil \& gas and the Indian public and private sectors. Of interest to this study is the paucity of information on (private) multi-national companies in the Nigerian oil and gas industry. The findings and recommendations of the reviewed literature revealed that the study of leadership behavior and its effect on employee productivity has immense potential for employees and organizational performance however there is a need for additional research on the private sector aspect of the Nigeria oil and gas industry. This study seeks to contribute to the existing body of knowledge from a Nigerian multi-national oil and gas company perspective. Consequently, the following hypotheses were construed:

H1. Autocratic leadership style positively affects employee productivity in Chevron Nigeria Limited.

H2. Democratic leadership style positively affects employee productivity in Chevron Nigeria Limited.

H3. Bureaucratic leadership style negatively affects employee productivity in Chevron Nigeria Limited.

H4. Laissez-faire leadership style negatively affects employee productivity in Chevron Nigeria Limited.

H5. Transactional leadership style positively affects employee productivity in Chevron Nigeria Limited.

H6. Charismatic leadership style positively affects employee productivity in Chevron Nigeria Limited.

\section{Methodology}

Research Design and Methodology: The primary goal of a research design is to ensure that the data obtained during the data collection phase is unambiguous and adequately sufficient to answer the research question(s). The study adopted a case study design; Chevron Nigeria Limited was selected as a case study for this research. According to Gaines (2018), the case study provides the researcher with a comprehensive understanding of the phenomena being studied through the collation of participant responses and an indepth understanding of real-life experiences relevant to the research study. The choice of Chevron Nigeria Limited as a case study is predicated on the fact that the company is one of the major oil and gas companies in 
Nigeria and a fair representation of the Nigerian oil and gas industry. The research population of this study is individuals working in the Nigerian upstream oil and gas industry. Due to the large size of the population and the impracticability of researching the entire population, the researcher has decided to restrict the research population to employees in Chevron Nigeria Limited, an international oil company and one of the major players in the Nigerian oil and gas industry. Chevron Nigeria Limited operates in five locations within Nigeria; these locations are Lekki-Lagos, Abuja, Warri, Escravos and Agbami FPSO.

The research population covers employees in these locations. Due to the geographical dispersion of employees, ease of deployment and storage, electronic questionnaires will be deployed to collect primary data from respondents. The essence of sampling is to enable the researcher to infer from an analysis of the sample a conclusion about the entire population. The research population of this study is individuals working in the Nigerian upstream oil and gas industry. Due to the large size of the population and the impracticability of researching the entire population, the researcher has decided to restrict the research sample to employees in Chevron Nigeria Limited. To mitigate researcher bias and ensure a representative sample is selected, respondents were selected via a simple random sampling selection method. According to Sharma (2017), the random sampling technique ensures each member of the population has an equal chance of being selected as a subject, is relatively easy to use, eliminates bias and when properly used ensures the sample selected is representative of the population (Odunlami \& Awolusi, 2015). The researcher used a sample of one hundred and twenty-five (125) respondents drawn from the company's five locations in Nigeria.

Data Collection and Ethical Considerations: Primary data was collected by deploying online questionnaires to the research sample. The online survey research method is quite advantageous as it leverages the internet to provide access to respondents who would have been difficult, if not impossible to reach through other channels (Wright, 2017). The questionnaires are self-administered via the use of a web link sent to respondents via email. The questionnaire was in two parts. The first section of the questionnaire was designed to obtain data about the respondents such as the age of respondents, gender, education levels, and length of service in the organization. The data in this section helped the researcher to understand the respondent's background. The second of the questionnaire was concerned with collecting data about the key variables of this research. The key variables are divided into two namely independent variables which are the prevalent leadership styles namely autocratic, bureaucratic, charismatic, laissez-faire, participative (democratic) and transformational. The Multifactor Leadership Questionnaire developed by Avolio and Bass was modified to enable the research to collect requisite data about the leadership behaviors prevalent in Chevron Nigeria Limited while subsequent questions sought to determine the level of employee productivity. Secondary data was collected via an extensive literature review of the existing body of knowledge.

To understand current literature on the research topic and the identification of research gaps. Ethics are the moral principles that govern a person's behavior and/or the conducting of an activity. The researcher needs to ensure all ethical issues are examined and reviewed throughout the research work as they are the standards for conduct that distinguish between right and wrong, protect the interest of the research respondents, eliminate bias and ensure the accuracy of research results (Easterby-Smith et al., 2012). Ethical issues considered during the research work include informed consent, confidentiality and anonymity, respect for privacy, objectivity and integrity. The researcher obtained a letter of consent from Chevron Nigeria Limited permitting the research to be conducted on the organization and questionnaires distributed to its employees. Measures implemented to ensure adherence to ethical standards include the collection of primary data electronically via an online survey hosted on surveymonkey.com. Minimal personally identifiable will be collected and respondents are under no compulsion to provide responses and have the option of submitting their responses anonymously. The survey contains a consent acknowledgment section that articulates the research study, the purpose of the research data collected and assurances of anonymity. Responses will be stored electronically and password-protected to ensure privacy and respondents can choose to respond anonymously.

Research Procedures: The questionnaire was preceded by an introductory letter that articulates the research study, the purpose of the research data collected, assurances of anonymity and confidentiality of responses received. Respondents are under no compulsion to provide responses however the questionnaire was designed to encourage respondent participation. The questionnaire was initially deployed to three 
respondents as a trial run; responses from this trial run were not included in the research sample. Feedback and responses received from the trial run were used to modify and refine the questionnaires to ensure that the questions and responses received were apt for the research study. The questionnaires were deployed via the company's email distribution list this ensured that everyone had an equal chance of being selected and reduced sampling bias.

Validity and Reliability Analysis: The research questionnaire utilized a five-level Likert scale to capture respondent responses. The Likert scale was designed by Rensis Likert in 1932 and is greatly utilized in management research to measure and evaluate people's attitudes, opinions and perceptions to questions and/or statements. The questionnaire had five questions (i.e. subscale) each for the six independent variables and the dependent variable. Cronbach's alpha was produced using a scale test and the results are presented in Table 1. The results show Cronbach's alphas over the conventional cut-off point of 0.7 , indicating that the subscales used were reliable and consistently capable of measuring the variables it is intended to measure.

Table 1: Reliability Statistics

\begin{tabular}{ll}
\hline Scale & Alpha \\
\hline Autocratic leadership & 0.833 \\
Democratic/participative leadership & 0.805 \\
Bureaucratic leadership & 0.756 \\
Laissez-faire leadership & 0.702 \\
Transaction leadership & 0.750 \\
Charismatic leadership & 0.941 \\
Employee productivity & 0.813 \\
\hline
\end{tabular}

Data Analysis and Presentation: Data collated via the online questionnaire deployed on Survey Monkey were exported into the Statistical Package for Social Sciences (SPSS) for analysis. SPSS was used to analyze the data collected using Multiple, linear regression. Multiple linear regression is regressions that contain two or more independent variables and one dependent variable. Multiple regression will be used to determine and understand the relationship between the independent variable (leadership styles) and dependent variable (employee productivity) of this study. Research work would be incomplete without data presentation. Data presentation involves the pictorial/graphical representation of data collected with the primary objective of summarizing and communicating the research data. The results of the data analysis will be presented via tables and charts (where necessary).

\section{Results and Discussion of Findings}

The questionnaire was distributed to one hundred and twenty-five (125) respondents and ninety-three (93) responses were received, resulting in a response rate of $74.4 \%$. According to Mugenda \& Mugenda (2003) cited in Maisiba et al. (2017), "a 50\% response rate is adequate, while response rate of above $60 \%$ and not exceeding 69 is good and a response rate above 69\% is rated very high"; they further posit that a high response rate would produce credible results. This study's response rate of $74.4 \%$ indicates that the response rate is very high and the results credible.

Multiple Regression Analysis: Multiple regression analysis was conducted to determine the effect of leadership styles (independent variables) on employees' productivity (dependent variable). The study adopted the following regression equation to establish the relationship between variables:

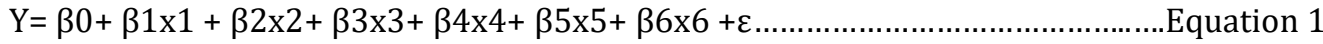

Where $Y=$ Employee productivity, $\beta 0=$ the constant of regression, $\beta 1, \beta 2, \beta 3, \beta 4, \beta 5$ and $\beta 6=$ are the regression coefficients/weights of the following respective independent variables: $\mathrm{x} 1=$ Autocratic leadership style, $\mathrm{x} 2=$ Democratic leadership style, $\mathrm{x} 3=$ Bureaucratic leadership style, $\mathrm{x} 4=$ Laissez-faire leadership style, $\mathrm{x} 5=$ Transact leadership style, $\mathrm{x} 6=$ Bureaucratic leadership style and $\varepsilon=$ error term. The six independent variables were measured using the responses obtained from the respondents. 
Demographic Analysis: The analysis of responses revealed that $46 \%$ of the respondents were male and $52 \%$ were female while $2 \%$ did not indicate their gender. The gender of respondents was relatively represented in this study. Table 1 shows the gender distribution. Respondents were requested to indicate their age. The analysis of responses revealed that $18.3 \%$ of the respondents were between the age of 20 to $30,52.7 \%$ were between the age of 31 to $40,25.8 \%$ were between the age of 41 to $50,1.1 \%$ were between the age of 51 to 60 while $2.1 \%$ did not indicate their age. The company's mandatory retirement age is 60 hence there are no respondents above the age of 60 . Table 2 shows the age distribution. Respondents were requested to indicate their level of education. The analysis of responses revealed that none of the respondents had an OND (Ordinary National Diploma).

51.6\% were either HND/B.Sc. (i.e. first degree) holders, $41.9 \%$ had a Master's degree, $1.1 \%$ had a Ph.D. while $5.4 \%$ either did not fall into any of these categories or did not indicate their level of education. Table 4.3 shows the level of the education distribution. Respondents were requested to indicate their number of years of service in their current organization; $32.3 \%$ of the respondents were between 0 to 5 years, $44.1 \%$ were between 6 to 10 years, $18.3 \%$ were between 11 to 15 years, $1.1 \%$ were between 16 to 20 years, $2.1 \%$ were above 20 years while $2.1 \%$ did not indicate their age. Table 2 shows the years of service distribution. Respondents were requested to indicate their level of motivation at work; $3.2 \%$ of the respondents indicated low, 9.7\% indicated moderately low, 33.3\% indicated medium, $41.9 \%$ indicated moderately high, 10.8\% indicated high while $1.1 \%$ did not indicate a response. Table 3 shows the level of motivation at work distribution.

Results: The effect of leadership styles on employee productivity.

\section{Correlation Analysis}

Table 2: Correlation Analysis of Dependent and Independent Variables

\begin{tabular}{|c|c|c|c|c|c|c|c|c|}
\hline \multicolumn{9}{|c|}{ Correlations $^{c}$} \\
\hline & & $\begin{array}{l}\text { Autocratic } \\
\text { leadership } \\
\text { style }\end{array}$ & $\begin{array}{l}\text { Democratic } \\
\text { leadership } \\
\text { style }\end{array}$ & $\begin{array}{l}\text { Bureaucratic } \\
\text { leadership } \\
\text { style }\end{array}$ & $\begin{array}{l}\text { Laissez-faire } \\
\text { leadership } \\
\text { style }\end{array}$ & $\begin{array}{l}\text { Transactional } \\
\text { leadership } \\
\text { style }\end{array}$ & $\begin{array}{l}\text { Charismatic } \\
\text { leadership } \\
\text { style }\end{array}$ & $\begin{array}{l}\text { Employee } \\
\text { Productivity }\end{array}$ \\
\hline \multirow[t]{2}{*}{$\begin{array}{l}\text { Autocratic leadership } \\
\text { style }\end{array}$} & $\begin{array}{l}\text { Pearson } \\
\text { Correlation }\end{array}$ & 1 & $-.790^{* *}$ & $.665^{*}$ & $-.337^{*}$ & $-.313^{* *}$ & $-.631^{*}$ & $-.503^{*}$ \\
\hline & Sig. (2-tailed) & & .000 & .000 & .002 & .004 & .000 & .000 \\
\hline \multirow[t]{2}{*}{$\begin{array}{l}\text { Democratic leadership } \\
\text { style }\end{array}$} & $\begin{array}{l}\text { Pearson } \\
\text { Correlation }\end{array}$ & $-.790^{\prime *}$ & 1 & $-.698^{* *}$ & $.335^{* *}$ & $.451^{* *}$ & $.756^{*}$ & $.612^{*}$ \\
\hline & Sig. (2-tailed) & .000 & & .000 & .002 & .000 & .000 & .000 \\
\hline \multirow[t]{2}{*}{$\begin{array}{l}\text { Bureaucratic leadership } \\
\text { style }\end{array}$} & $\begin{array}{l}\text { Pearson } \\
\text { Correlation }\end{array}$ & $.665^{* *}$ & $-.698^{* *}$ & 1 & $-.382^{* *}$ & $-.294^{* *}$ & $-.555^{*}$ & $-.421^{* *}$ \\
\hline & Sig. (2-tailed) & .000 & .000 & & .000 & .006 & .000 & .000 \\
\hline \multirow[t]{2}{*}{$\begin{array}{l}\text { Laissez-faire leadership } \\
\text { style }\end{array}$} & $\begin{array}{l}\text { Pearson } \\
\text { Correlation }\end{array}$ & $-.337^{* *}$ & $.335^{* *}$ & $-.382^{* *}$ & 1 & $.238^{\circ}$ & $.270^{\circ}$ & .199 \\
\hline & Sig. (2-tailed) & .002 & .002 & .000 & & .028 & .012 & .068 \\
\hline \multirow[t]{2}{*}{$\begin{array}{l}\text { Transactional leadership } \\
\text { style }\end{array}$} & $\begin{array}{l}\text { Pearson } \\
\text { Correlation }\end{array}$ & $-.313^{*}$ & $.451^{* *}$ & $-.294^{* *}$ & $.238^{*}$ & 1 & $.627^{*}$ & $.275^{\circ}$ \\
\hline & Sig. (2-tailed) & .004 & .000 & .006 & .028 & & .000 & .011 \\
\hline \multirow[t]{2}{*}{$\begin{array}{l}\text { Charismatic leadership } \\
\text { style }\end{array}$} & $\begin{array}{l}\text { Pearson } \\
\text { Correlation }\end{array}$ & $-.631^{*}$ & $.756^{*}$ & $-.555^{* *}$ & $.270^{\circ}$ & $.627^{*}$ & 1 & $.612^{*}$ \\
\hline & Sig. (2-tailed) & .000 & .000 & .000 & .012 & .000 & & .000 \\
\hline \multirow[t]{2}{*}{ Employee Productivity } & $\begin{array}{l}\text { Pearson } \\
\text { Correlation }\end{array}$ & $-.503^{*}$ & $.612^{*}$ & $-.421^{* *}$ & .199 & $.275^{\circ}$ & $.612^{*}$ & 1 \\
\hline & Sig. (2-tailed) & .000 & .000 & .000 & .068 & .011 & .000 & \\
\hline
\end{tabular}

The correlation analysis in table 1 revealed that democratic leadership style $(\mathrm{M}=2.61, \mathrm{SD}=1.14)$ and charismatic leadership style $(M=3.72, S D=1.00)$ positively correlated with employee productivity $(M=4.04$, $\mathrm{SD}=0.85)$ with correlation coefficients of 0.612 while transaction leadership style $(\mathrm{M}=3.45, \mathrm{SD}=1.03)$ has a 
weak positive correlation of 0.275 with employee productivity $(M=4.04, S D=0.85)$. Autocratic Leadership style $(M=2.61, S D=1.14)$ and bureaucratic leadership style negatively correlated with employee productivity $(\mathrm{M}=4.04, \mathrm{SD}=0.85)$ with correlation coefficients of -0.503 and -0.421 while the coefficient of correlation of 0.199 indicated there was no significant correlation between Laissez faire leadership style $(\mathrm{M}=$ $3.28, \mathrm{SD}=1.06$ ) and employee productivity.

Normality, Homoscedasticity and Multicollinearity: The P-Plot of regression standardized residual in table 1 indicates that the dataset follows the normality line. The absence of drastic deviations from the normality line is indicative that normality can be assumed. Homoscedasticity is concerned with whether the variance of the errors from regression is dependent on the values of the independent variables. The scatter plot of the residuals in table 2 indicates the homoscedastic nature of the research data (residuals) viz-a-vis the regression analysis. Multicollinearity statistics in table 5 indicate tolerance numbers ranging from 0.240 to 0.826 while Variance Inflation factors (VIFs) ranged from 1.211 to 4.170. According to Vatcheva et al. (2016), VIF values greater than ten (10) are suggested for detecting multicollinearity; the VIF values of the independent variables indicate that that multicollinearity is not suspected.

\section{Table 3: Model Summary}

\begin{tabular}{lllll} 
Model & R & R Square & Adjusted R Square & Std. Error of the Estimate \\
\hline 1 & $.667^{\mathrm{a}}$ & .445 & .402 & .429
\end{tabular}

a. Predictors: (Constant), Charismatic leadership style, Laissez-faire leadership style, Bureaucratic leadership style, transactional leadership style, Autocratic leadership style, Democratic leadership style

Table 3 depicts a summary of the model which indicates that leadership styles are responsible for $44.5 \%$ of the variability in employee's productivity; this is evidenced by the R square statistics of 0.445 .

Table 4: Analysis of Variance

\begin{tabular}{lllllll}
\hline Model & Sum of Squares & DF & Mean Square & F & Sig. \\
\hline 1 & Regression & 11.476 & 6 & 1.913 & 10.412 & $.000^{\mathrm{b}}$ \\
Residual & 14.329 & 78 & .184 & & \\
& Total & 25.805 & 84 & & &
\end{tabular}

a. Dependent Variable: Employee Productivity

b. Predictors: (Constant), Charismatic leadership style, Laissez-faire leadership style, Bureaucratic leadership style, transactional leadership style, Autocratic leadership style, Democratic leadership style

Table 4 presents the analysis of variance (ANOVA). ANOVA was used to establish the significance of the regression model. The Sig. value of $0.000(p=0.000<0.05)$ indicates that the model has a confidence level greater than $95 \%$ and is statistically significant in predicting how autocratic leadership style, democratic leadership style, bureaucratic leadership style, laissez-faire leadership style, transactional leadership style and charismatic leadership style influences employee productivity.

Table 5: Regression Coefficients

\begin{tabular}{|c|c|c|c|c|c|c|c|}
\hline \multirow[b]{2}{*}{ Model } & \multicolumn{2}{|c|}{$\begin{array}{l}\text { Unstandardized } \\
\text { Coefficients }\end{array}$} & \multicolumn{2}{|c|}{$\begin{array}{l}\text { Standardized } \\
\text { Coefficients }\end{array}$} & \multirow[b]{2}{*}{ Sig. } & \multicolumn{2}{|c|}{$\begin{array}{l}\text { Collinearity } \\
\text { Statistics }\end{array}$} \\
\hline & B & Std. Error & Beta & $t$ & & Tolerance & VIF \\
\hline (Constant) & 2.356 & 0.678 & & 3.474 & 0.001 & & \\
\hline $\begin{array}{l}\text { Autocratic leadership } \\
\text { style }\end{array}$ & -0.001 & 0.082 & -0.002 & -0.013 & 0.990 & 0.340 & 2.942 \\
\hline $\begin{array}{l}\text { 1Democratic leadership } \\
\text { style }\end{array}$ & 0.229 & 0.108 & 0.364 & 2.114 & 0.038 & 0.240 & 4.170 \\
\hline $\begin{array}{l}\text { Bureaucratic leadership } \\
\text { style }\end{array}$ & 0.036 & 0.096 & 0.046 & 0.372 & 0.711 & 0.458 & 2.183 \\
\hline
\end{tabular}




\begin{tabular}{llllllll}
\hline $\begin{array}{l}\text { Laissez-faire leadership } \\
\text { style }\end{array}$ & 0.007 & 0.071 & 0.009 & 0.095 & 0.925 & 0.826 & 1.211 \\
$\begin{array}{l}\text { Transactional } \\
\text { leadership style }\end{array}$ & -0.120 & 0.077 & -0.171 & -1.546 & 0.126 & 0.582 & 1.718 \\
$\begin{array}{l}\text { Charismatic leadership } \\
\text { style }\end{array}$ & 0.304 & 0.098 & 0.467 & 3.116 & 0.003 & 0.317 & 3.150 \\
$\begin{array}{l}\text { a. Dependent Variable: Employee Productivity } \\
\text { l. }\end{array}$ & & & & & \\
\hline
\end{tabular}

Based on the outcome of the analysis presented in table 4.19, the relationship between the dependent and independent variables can be represented using the following regression equation:

$\mathrm{Y}=2.356+-0.001(\mathrm{x} 1)+0.229(\mathrm{x} 2)+0.036(\mathrm{x} 3)+0.007(\mathrm{x} 4)+-0.120(\mathrm{x} 5)+0.304(\mathrm{x} 6)$

The coefficients results show that charismatic and democratic leadership styles significantly positively predict employee productivity with standardized B's of $0.467(\mathrm{p}<0.01)$ and $0.364(\mathrm{p}<0.01)$; this implies that the productivity of employees whose immediate leaders exhibit charismatic leadership characteristics improved by $30.4 \%$ while the productivity of employees whose immediate leaders exhibit democratic leadership styles improved by $22.9 \%$. The results also suggest that bureaucratic and laissez-faire leadership styles insignificantly positively predict employee productivity while autocratic and transactional leadership styles insignificantly negatively predict employee productivity.

\section{Discussion of Findings}

Leadership Styles Prevalent in Chevron Nigeria Limited: The findings of this study and the examination of the responses received from the questionnaire indicate there are varied leadership styles exhibited and prevalent in Chevron Nigeria Limited. The research findings as presented in the table indicate that while there are several leadership styles practiced in Chevron Nigeria Limited, autocratic leadership $(S D=1.14)$ is the most prevalent leadership style followed by laissez-faire $(S D=1.06)$, bureaucratic $(S D=1.04)$ and transactional leadership style (SD = 1.03). Democratic and charismatic leadership are the least prevalent leadership styles in Chevron Nigeria Limited.

Influence of Leadership Style on the Employee Job Performance: The findings of the study affirm that leadership style influences employee productivity; this is consistent with studies by Babatunde (2015), Basit et al. (2017), Lawal \& Osifo (2018) and Ohemeng et al. (2018). The research findings indicate that charismatic and democratic leadership styles significantly positively influence employee productivity, bureaucratic and laissez-faire leadership styles have a minimal positive effect on employee productivity while autocratic and transactional leadership styles insignificantly negatively influence employee productivity. The predictions of the regression model establish that while a unit increase in charismatic, democratic, bureaucratic and laissezfaire leadership style leads to a $30.4 \%, 22.9 \%, 3.6 \%$, and $0.7 \%$ increase in employee productivity respectively, a unit increase in autocratic and transactional leadership style results in a $0.1 \%$ and $12.0 \%$ decline in employee productivity. The research findings from previous studies are varied with some studies reaffirming this study's findings while others have a contrary view. Amiscua et al. (2018) posit that democratic leadership style has a positive impact on motivation and employee productivity; this is further corroborated by Sayedi (2016)'s findings that conclude that autocratic leadership style and democratic leadership style have a significant positive impact on employee's productivity while laissez-faire negatively impacts employee productivity.

Sayedi's finding while corroborating this study's findings on the impact of democratic leadership style on employee productivity disagrees with the impact of autocratic and laissez-faire leadership styles however this is supported by Rehman et al. (2018) who maintain that laissez-faire and transactional leadership styles are positively correlated to employee productivity. Other studies such as Erskine \& Georgiou (2017) affirm that transactional and charismatic leadership styles positively affect employee productivity while laissezfaire and autocratic leadership styles negatively affect employee productivity while Obasan \& Hassan (2014) maintain that transactional and laissez-faire leadership styles have a negative impact on employee productivity. While there are varied opinions on the impact of leadership styles on employee productivity, a 
common premise among the reviewed existing body of knowledge is that leadership styles affect employee productivity and the application of a suitable leadership style will greatly improve employee productivity and organizational success. The observed differences in research studies on leadership styles and employee productivity could be attributable to other factors such as organizational culture, power-distance culture, staff composition \& demographics, nature of operating industry, etc. It is recommended that these factors be considered in future research studies on the subject matter.

In summary, a review of the multiple regression analysis conducted revealed that autocratic leadership style is negatively correlated to, and insignificantly negatively predict employee productivity. This result does not support the first hypothesis of this study which states that "autocratic leadership style positively affects employee productivity in Chevron Nigeria Limited". The results of the multiple regression analysis also posit that leaders that exhibit charismatic and democratic leadership traits significantly positively affect employee productivity which supports the second and sixth hypotheses of this study; however, the research findings were antithetical to the third, fourth and fifth hypotheses of this study as bureaucratic and laissez-faire leadership styles insignificantly positively predict employee productivity while transactional leadership styles insignificantly negatively predict employee productivity. The results of this study are consistent with the results of most of the previous studies reviewed in Chapter two such as Pradeep \& Prabhu (2011), Singh (2015), Marcus et al. (2017) and Ajibade et al. (2017). This study, therefore, contributes to the expansion of knowledge in the social science field on the effect the different leadership styles have on employee productivity. It also sought to close the existing gap in current literature by providing reference studies on the impact of leadership styles and employee productivity in multinational oil and gas companies in Nigeria; hitherto there was a paucity of research data in this regard.

\section{Summary, Conclusion and Policy Recommendations}

Summary: This study seeks to understand the effect leadership styles have on employee productivity in the Nigerian oil and gas industry using Chevron Nigeria limited as a case study. The choice of Chevron Nigeria Limited as the case study for this research is predicated on the fact that the company is one of the major oil and gas companies in Nigeria and a fair representation of the Nigerian oil and gas industry. The findings of this study are anticipated to improve employee productivity through effective leadership practice. Six different leadership styles were identified and their effect on employee productivity was reviewed. The review of existing literature conducted revealed that although the study of leadership behavior and its effect on employee productivity has immense potential for employees and organizational performance, there is no universally acceptable hypothesis on leadership style and employee productivity with several studies having conflicting findings. The research sample was selected using a random sampling method. The random sampling technique ensures each member of the population has an equal chance of being selected as a subject, is relatively easy to use, eliminates bias and when properly used ensures the sample selected is representative of the population (Sharma, 2017). Primary data was collected by deploying an online questionnaire to a sample size of one hundred and twenty-five respondents with ninety-three valid responses received. According to Mugenda \& Mugenda (2003) cited in Maisiba et al. (2017), this study's response rate of $74.4 \%$ indicates that the response rate is very high and the results credible.

Research data were analyzed using SPSS. Correlation and regression analysis were utilized in analyzing the data and testing the research hypothesis. Normality, Homoscedasticity and Multicollinearity tests were conducted and the results reaffirm the suitability of research data in evaluating the study's hypothesis. The analysis of leadership styles prevalent in Chevron Nigeria Limited revealed that the autocratic leadership style is the most predominant leadership style followed by laissez-faire, bureaucratic, transactional, democratic and charismatic leadership styles. The research findings indicate that charismatic and democratic leadership styles improve employee productivity while the productivity of employees whose immediate leaders exhibit bureaucratic and laissez-faire leadership styles was insignificantly improved. Autocratic and transactional leadership styles were discovered to have a minimal negative impact on employee productivity. From the foregoing, the least prevalent leadership styles in Chevron Nigeria limited are best suited to improving employee productivity while the most prevalent leadership style (autocratic leadership style) has been indicated as inimical to employee productivity. Employee productivity can be improved within the organization from a leadership perspective by either orientating existing leaders to exhibit more desirable 
leadership styles or promoting/recruiting new leaders that exhibit leadership styles that motivate improved productivity from their subordinates.

Conclusion: Employee productivity is fundamental to the growth, profitability and continued existence of any organization. In conclusion, the present study indicates that leadership style viz-a-vis the quality and practice of leadership impacts employee productivity. Specifically, charismatic leadership styles and democratic leadership styles are best suited to improving employee productivity, bureaucratic and laissezfaire leadership styles exert a minimal positive effect on employee productivity while transactional and autocratic leadership styles impede employee productivity. While the choice of leadership style impacts employee productivity, the results of this study also indicate that other factors exist that influence employee productivity and these factors should be identified and researched to enable researchers, leaders and academia to have a well-rounded understanding of determinants of employee productivity.

Recommendation and Implications: The primary goal of any organization is to maximize profits; one of the ways organizations can maximize profitability is through improved employee productivity. The findings of this study indicate that the prevalent leadership style in an organization is an important influencer of employee productivity and ultimately profitability. The findings of this study are consistent with the finding of other studies such as Obasan \& Hassan (2014), Erskine \& Georgiou (2017) and Rehman et al. (2018). It is therefore recommended that organizations in the Nigerian oil and gas industry should constantly influence leadership behavior to maximize employee productivity; this can be achieved through policy formulation, recruitment, training and promotion as well as by enforcing the appropriate organizational behaviors. This study's findings indicate that the existing mix of leadership styles prevalent in Chevron Nigeria Limited does not maximize the productivity of its employees as the primary leadership style of autocratic negatively impacts employee productivity. It is recommended that the organization review its leadership training and selection processes to maximize its leadership pool with the desirable goal of maximizing employee productivity. Regular pulse checks should be conducted to ascertain that the current leadership style in the organization and interventions implemented to ensure the desired leadership mix/style is maintained.

Future studies should examine the impact of other factors such as cultural differences, employee attitude and expectations, organizational policies and power distance and how they inter-relate with leadership styles and employee productivity. This study indicates that organizations should pay attention to the leadership styles needs of their employees if they desire improved employee productivity. While some leadership styles improve employee productivity, others impair productivity; the onus on the discerning organization is to determine the prevalent leadership styles and required leadership styles to maximize employee productivity and enact training and policies to bridge identified gaps. The study contributes to the existing literature on leadership behavior and its effect on employee productivity and also validates the findings and relevance of the body of knowledge reviewed in Chapter two. This study is also intended to be a reference point to scholars and researchers for further studies on leadership practice and other related subject matters. However, the first and possibly most important limitation of this study is that the research sought to determine the effect of leadership styles on employee productivity by examining only one organization; this is closely related to the next limitation which has to do with sampling. This research was conducted using primary data generated from ninety-three (93) respondents.

The inherent limitations of sampling technique such as sampling bias, the possibility of lack of representativeness of the population and respondent bias constitute the limitations of this study. This study examined the effect of leadership styles on workers' performance by studying only one organization. It is recommended that future studies increase the research scope to cover more than one organization and also consider investigating other factors that influence employee productivity such as organizational structure, gender, level of education, corporate culture, etc. with a view of determining if the interaction of leadership styles with these other factors further enhance or impede employee productivity. Future researchers can also use a larger sample size spanning several organizations in dissimilar industries to reduce the risks associated with sampling and drawing inferences from a sample. 


\section{References}

Ajibade, E., Ajayi, O. \& Shobowale, O. (2017). Leadership Styles and Employees' Performance in Nigerian Federal Polytechnics: A Study of Federal Polytechnic, Ilaro, Ogun State. Journal of Public Administration, Finance and Law, 11(1), 17-30.

Amiscua, M., Fernandez, M., Madanging, J. \& Querido, J. (2018). The Impact of Leadership Styles on Employees' Productivity: A Qualitative Study of Employees' Experiences of Motivation in the Workplace. Available at: https://www.researchgate.net/requests/attachment/52212945 (Accessed 29/12/18)

Aunga, D. \& Masare, O. (2017). Effect of Leadership Styles on Teacher's Performance in Primary Schools of Arusha District Tanzania. International Journal of Educational Policy Research and Review, 14(4), 4252.

Babatunde, O. (2015). The impact of leadership style on employee's performance in an organization, Public Policy and Administration Research, 5(1), 195-206.

Basit, A., Sebastian, V. \& Hassan, Z. (2017). Impact of Leadership Style on Employee Performance (A case study on a private organization in Malaysia). International Journal of Accounting \& Business Management, 5(2), 112-130.

Bass, B. M. \& Avolio, B. J. (2000). MLQ Multifactor Leadership Questionnaire. Redwood City: Mind Garden.

Blazi, C. \& Awolusi, O. D. (2020). Employee Engagement in Multinational Diverse Organization in Difficult Terrain: A Study of Non-Family Station Organization, Information Management and Business Review, 12(1), 45-62.

Chevron. (2018). 2017 Corporate Responsibility Report Highlights. Available at: https://www.chevron.com//media/shared-media/documents/2017-corporate-responsibility-report.pdf (Accessed 11/09/18).

Chowdhury, R. G. (2014). A Study on the Impact of Leadership Styles on Employee Motivation and Commitment: An Empirical Study of Selected Organizations in the Corporate Sector. Available at: http://www.dypatil.edu/schools/management/wp-content/uploads/2015/11/A-study-of-theImpact-of-Leadership-Styles-on-Employee-Motivation-and-Commitment-An-empirical-study-ofselected-organisations-in-Corporate-sector-Rima-Chowdhury.pdf (Accessed 22/09/18).

Chowdhury, R. \& Gopal, R. (2014). Leadership Styles and Employee Motivation: An Empirical Investigation in a Leading Oil Company in India. International Journal of Research in Business Management, 2(5), 1-10.

Dalluay, V. S. \& Jalagat, R. C. (2016). Impacts of Leadership Style Effectiveness of Managers and Department Heads to Employees' Job Satisfaction and Performance on Selected Small-Scale Businesses in Cavite, Philippines. International Journal of Recent Advances in Organizational Behavior \& Decision Sciences, 2(2), 734-751.

Easterby-Smith, M., Thorpe, R. \& Jackson, P. (2012). Management Research. 4th ed. London: Sage Publications.

Erskine, J. \& Georgiou, G. (2017). Leadership Styles: Employee Stress, Well-being, Productivity, Turnover and Absenteeism. Available at: https://www.researchgate.net/requests/attachment/52212988 (Accessed 01/01/19).

Ewell, J. (2018). Revitalizing a Student Organization by Applying Transformational Leadership. Journal of Leadership Education, 17(3), 208-218.

Gaines, T. M. (2018). Strategies for virtual sales leaders to increase the productivity of remote employees. Available at: https://scholarworks.waldenu.edu/cgi/viewcontent.cgi?article=6287\&context=dissertations (Assessed 03/10/18).

Gastil, J. (2012). A meta-analytic review of the productivity and satisfaction of democratic and autocratic leadership. Small-Group Research, 25(3), 384-410.

Graham, J. \& Trendafilova, S. (2016). Implementing Self-Managed Teams at Western University: A Human Resource and Leadership Case Study. Case Studies in Sport Management, 5(1), 64-72.

Getachew, D. S. \& Erhua Z. (2018). The Influences of Transformational Leadership on Collective Efficacy: The Moderating Role of Perceived Organizational Support. International Journal of Organizational Innovation, 10(4), 7-15.

Hassan, S. (2016). Impact of HRM Practices on Employee's Performance. International Journal of Academic Research in Accounting, Finance and Management Sciences, 6(1), 15-22.

House, R. J. (1971). A Path-Goal Theory of Leader Effectiveness. Journal of Administrative Science Quarterly, 16(1), 321-338. 
Iqbal, N., Anwar, S. \& Haider, N. (2015). Effect of Leadership Style on Employee Performance. Arabian Journal of Business and Management Review, 5(5), 1-6.

Ispas, A. (2012). The Perceived Leadership Style and Employee Performance in the Hotel Industry - a Dual Approach. Review of International Comparative Management / Revista De Management Comparat International, 13(2), 294-304.

Kagwiria, L. (2016). Influence of Leadership on Employee Productivity at KCB Bank Kenya Ltd, Nairobi Region Branches. Available at: http://erepository.uonbi.ac.ke/bitstream/handle/11295/98559/LILIAN\%20FINAL\%20PROJECT.pd f? sequence=1\&isAllowed=y (Accessed 22/09/18).

Kohn, A. (1993). Why Incentive Plans Cannot Work. HBR. Available at: https://hbr.org/1993/09/whyincentive-plans-cannot-work (Accessed 10/06/18).

Lawal, B. A. \& Osifo S. J. (2018). Leadership Styles and Employee Performance: Empirical Evidence from Selected Banks in Edo State. Available at: https://www.researchgate.net/publication/329659647_Leadership_Styles_and_Employee_performa nce_Empirical_Evidence_from_Selected_Banks_in_Edo_State (Accessed 24/12/18).

Luo, H. \& Liu, S. (2014). Effect of Situational Leadership and Employee Readiness Match on Organizational Citizenship Behavior in China. Social Behavior \& Personality: an international journal, 42(10), 17251732.

Maisiba, N. L., Muturi, W. \& Atambo, W. (2017). Effects of Working Capital Management on the profitability of Retail Firms in Kisii County, Kenya. International Journal of Social Sciences and Information Technology, 3(2), 23-36.

Malik, S. H. (2013). Relationship between Leader Behaviors and Employees' Job Satisfaction: A Path-Goal Approach. Pakistan Journal of Commerce \& Social Sciences, 7(1), 209-222.

Mangale, M. N. (2017). The Effects of Compensation on Employee Productivity: A Case Study of Kenya Literature Bureau, South C Nairobi. Available at: http://repository.mua.ac.ke/1570/1/Proposal.pdf (Accessed 22/09/2018).

Marcus, G., Olowu, D., Solomon, A. \& Akhimien, E. (2017). Leadership Styles and Employee Performance in Nigerian Higher Educational Institutions. American Journal of Environmental and Resource Economics, 12(1), 12-21.

Matira, K. M. \& Awolusi, O. D. (2020). Leaders and Managers Styles towards Employee Centricity: A Study of Hospitality Industry in the United Arab Emirates, Information Management and Business Review, 12(1), 1-21.

Men, L. R. \& Stacks, D. W. (2013). The impact of leadership style and employee empowerment on perceived organizational reputation. Journal of Communication Management, 17(2), 171-192.

Mukonga, L. M. \& Awolusi, O. D. (2019). Strategic Leadership in the Post-Conflict States: A Study of the Democratic Republic of Congo (DRC), Journal of Social and Development Sciences, 10(4), 36-51.

Mulki, J. P., Caemmerer, B. \& Heggde, G. S. (2015). Leadership style, salesperson's work effort and job performance: the influence of power distance. Journal of Personal Selling \& Sales Management, 35(1), 3-22.

Munir, F. \& Aboidullah M. (2018). Gender Differences in Transformational Leadership Behaviors of School Principals and Teachers' Academic Effectiveness. Bulletin of Education \& Research, 40(1), 99-113.

Mwangi, P. K. (2014). The Effect of Compensation on Employee Motivation: A Case study of Chloride Exide. Available http://erepo.usiu.ac.ke/bitstream/handle/11732/161/Patrick\%20Mwangi.pdf?sequence=1\&isAllo wed=y (Accessed 24/09/18).

Obasan, K. \& Banjo, H. (2014). A Test of the Impact of Leadership Styles on Employee Performance: A Study of Department of Petroleum Resources. Available at: https://www.researchgate.net/publication/311231059_A_Test_of_the_Impact_of_Leadership_Styles_ on_Employee_Performance_A_Study_of_Department_of_Petroleum_Resources (Accessed 24/09/15).

Odunlami, S. A. \& Awolusi, O. D. (2015). Multinational Corporation and economic development in Nigeria, American Journal of Environmental Policy and Management, 1(2), 16-24.

Ohemeng, F., Amoaks-Asiedu, E. \& Darko, T. (2018). The relationship between leadership style and employee performance: An exploratory study of the Ghanaian public service. International Journal of Public Leadership, 14(4), 274-296. 
Ojeleye, Y. C. (2017). The Impact of Remuneration on Employees' Performance: A Study of Abdul Gusau Polytechnic, Talata-Mafara and State College of Education Maru, Zamfara State. Arabian Journal of Business and Management Review (Nigerian Chapter), 4(2), 34-43.

Olatunji, O. O. \& Awolusi, O. D. (2019). Performance Evaluation and Improvement among Salesmen in the Nigerian Fast Moving Consumer Goods Sector, Journal of Social and Development Sciences, 10(4), 1229.

Onuoha, A. (2017). Top 50 Best Paying Companies in Nigeria. iDONSABI. Available at: https://idonsabi.com/top-50-best-paying-companies-in-nigeria/ (Accessed 08/06/18).

Pradeep, D. \& Prabhu, V. (2011). The Relationship between Effective Leadership and Employee Performance. 2011 International Conference on Advancements in Information Technology. Available at: https://pdfs.semanticscholar.org/2dc9/c1b1b36a7ac68a4b75b61d07a33860a28017.pdf (Accessed 23/09/18).

Rego, A., Sousa, F., Marques, C. \& Cunha, M. (2012). Authentic leadership promoting employees' psychological capital and creativity. Journal of Business Research, 65(1), 429-437.

Rehman, S., Rahman, H., Zahid, M. \& Asif, M. (2018). Leadership Styles, Organizational Culture and Employees' Productivity: Fresh Evidence from Private Banks of Khyber-Pakhtunkhwa, Pakistan. Abasyn University Journal of Social Sciences, 1-15.

Sayedi, N. S. (2016). Impact of Leadership Style on Employees' Motivation: A Case Study of Access Bank Nigeria.

Available

at: https://www.researchgate.net/publication/328803891_Impact_of_Leadership_Style_on_Employees \%27_Motivation_A_Case_Study_of_Access_Bank_Nigeria (Accessed 26/12/18).

Sharma, G. (2017). Pros and cons of different sampling techniques. International Journal of Applied Research, $3(7), 749-752$.

Singh, K. (2015). Leadership Style and Employee Productivity: A Case Study of Indian Banking Organizations. Journal of Knowledge Globalization, 8(2), 39-67.

Vatcheva, K., Lee, M., McCormick, J. \& Rahbar, M. (2016). Multicollinearity in Regression Analyses Conducted in Epidemiologic Studies. Epidemiol, 6(2), 23-34.

Wilfred, N. O., Elijah, M. C. \& Muturi, M. W. (2014). Effect of Remuneration on Employees Performance in the Ministry of Internal Security: A Case of Kisii County. International Journal of Human Resource Studies, 4(1), 223-231.

Wright, K. (2017). Researching Internet-Based Populations: Advantages and Disadvantages of Online Survey Research, Online Questionnaire Authoring Software Packages, and Web Survey Services. Journal of Computer-Mediated Communication, 10(3), 23-35. 